\title{
Correction to: Analyzing outliers activity from the time-series transaction pattern of bitcoin blockchain
}

\author{
Rubaiyat Islam $^{1} \cdot$ Yoshi Fujiwara $^{1} \cdot$ Shinya Kawata ${ }^{1,2} \cdot$ Hiwon Yoon $^{2}$
}

Published online: 14 June 2021

(c) The Author(s) 2021

\section{Correction to: Evolutionary and Institutional Economics Review (2019) 16:239-257 \\ https://doi.org/10.1007/s40844-018-0107-8}

The article "Analyzing outliers activity from the time-series transaction pattern of bitcoin blockchain", written by Rubaiyat Islam, Yoshi Fujiwara, Shinya Kawata and Hiwon Yoon, was originally published Online First without Open Access. After publication in volume 16, issue 1, pages 239-257 the author decided to opt for Open Choice and to make the article an Open Access publication. Therefore, the copyright of the article has been changed to (C) The Author(s) 2021 and the article is forthwith distributed under the terms of the Creative Commons Attribution-NonCommercial 4.0 International License, which permits any non-commercial use, sharing, adaptation, distribution and reproduction in any medium or format, as long as you give appropriate credit to the original author(s) and the source, provide a link to the Creative Commons licence, and indicate if changes were made. The images or other third party material in this article are included in the article's Creative Commons licence, unless indicated otherwise in a credit line to the material. If material is not included in the article's Creative Commons licence and your intended use is not permitted by

The original article can be found online at https://doi.org/10.1007/s40844-018-0107-8.

Rubaiyat Islam

sb17q002@ai.u-hyogo.ac.jp

Yoshi Fujiwara

yoshi@sim.u-hyogo.ac.jp

Shinya Kawata

kawata@cmdlab.co.jp

Hiwon Yoon

yoon@cmdlab.co.jp

1 Graduate School of Simulation Studies, University of Hyogo, Kobe, Japan

2 CMD Lab, Inc., Tokyo, Japan 
statutory regulation or exceeds the permitted use, you will need to obtain permission directly from the copyright holder to view a copy of this licence, visit http://creat ivecommons.org/licenses/by-nc/4.0/.

The original article has been corrected.

Open Access This article is licensed under a Creative Commons Attribution-NonCommercial 4.0 International License, which permits any non-commercial use, sharing, adaptation, distribution and reproduction in any medium or format, as long as you give appropriate credit to the original author(s) and the source, provide a link to the Creative Commons licence, and indicate if changes were made. The images or other third party material in this article are included in the article's Creative Commons licence, unless indicated otherwise in a credit line to the material. If material is not included in the article's Creative Commons licence and your intended use is not permitted by statutory regulation or exceeds the permitted use, you will need to obtain permission directly from the copyright holder. To view a copy of this licence, visit http://creativecommons.org/licenses/by-nc/4.0/.

Publisher's Note Springer Nature remains neutral with regard to jurisdictional claims in published maps and institutional affiliations. 